\title{
Relationship between Liquidity Risk and Net Interest Margin of Conventional Banks in Bangladesh
}

\author{
A. N. M. Minhajul Haque Chowdhury ${ }^{1 *}$, Ayesha Siddiqua ${ }^{2}$, Abu Sayed Md. Mahmudul Haque Chowdhury ${ }^{3}$ \\ ${ }^{1,2}$ MBA Student, Department of Finance and Banking, Hajee Mohammad Danesh Science and Technology University, Dinajpur-5200, \\ BANGLADESH \\ ${ }^{3}$ Senior Lecturer, Department of English, University of Development Alternative, Dhaka-1209, BANGLADESH \\ *E-mail for correspondence: mhchowdhury2016@gmail.com
}

DOI: https://doi.org/10.18034/abr.v6i3.43

\begin{abstract}
Net interest margin (NIM) of a bank depends on several firm-specific factors. The aim of the study was to determine the effect of liquidity risk on the profitability indicating variable NIM of the conventional banks in Bangladesh. Seven banks were analyzed using the annual reports of the banks for the period of 2011 to 2015. Researchers applied descriptive statistics, correlation, and regression analysis to find out the results. The findings of the study provided evidence that cash to asset (CA) ratio had a negative relationship with NIM but a loan to asset (LA) ratio had a positive effect on the NIM. There was also a significant positive relationship between NIM and loan to deposit (LD) ratio. From the regression analysis it was clear that the LD, CA, and LA were able to explain the changes of NIM of the banks.
\end{abstract}

\section{JEL Classifications: $G 21$}

Keywords: Conventional banks, net interest margin, liquidity risk, profitability

\section{INTRODUCTION}

The main earning source of conventional banks is net interest income. The profitability of the banks depends much on this net interest income. This study used net interest margin as the performance indicator of the conventional banks and analyzed different liquidity risk ratios such as loan to deposit ratio (LD), cash to asset ratio (CA) and loan to asset ratio (LA) to identify the effect of these on the profitability of the conventional banks.

\section{Objective of the Study}

The study was constructed with the objective to determine the influence of liquidity risk on net interest margin of the selected conventional banks in Bangladesh.

\section{LITERATURE REVIEW}

Saksonova (2014) argued that net interest margin was the most appropriate criterion for the evaluation of the effectiveness of banks. He further said that it was superior to the return on the asset as it measured how effectively a bank manages its interest-bearing asset. Youssef and Samir (2015) conducted a comparative study on the financial performance of Islamic and conventional banks in Egypt where liquidity was a factor of profitability measurement. The result indicated that the profitability of the commercial banks was significantly and positively related to the liquidity. Hamadi and Awdeh (2012) investigated the Lebanese banking sector to find out the determinants that had an effect on the net interest margin of the banks. They summed up that size of the bank, liquidity, capitalization and credit risk did not have the significant effect on the net interest margin of the banks. Raharjo et al. (2014) used some internal factor (growth of bank's asset, profitability, efficiency, capital adequacy, liquidity, and risk) and external factors (market power, inflation and interest rate to find out the significant determinants those had an effect on net interest margin of the commercial banks in Indonesia. Loan to deposit ratio was the indicator of liquidity of banks. Their analysis reflected that the increase in loan to deposit ratio had significant positive influence on the net interest margin of the banks. Rahman et al. (2015) argued that capital strength, credit risk, ownership structure, bank size, noninterest income, cost efficiency, off-balance sheet activities and liquidity was potential bank-specific factors 
those determined the return on asset (ROA), return on equity (ROE) and net interest margin (NIM) of the banks in Bangladesh. Lartey et al. (2013) investigated seven listed banks in Ghana Stock Exchange for the year 2005-2010 to trace out the relationship between liquidity and profitability of the banks. They used time series analysis for the study and found that liquidity and profitability of the selected banks were related, but there was no strong positive relationship between the variables. Béjaoui and Bouzgarron (2014) studied the determinants of profitability and argued that liquidity of the banks was negatively related to the profitability of the banks in Tunisia. Dawood (2014) investigated 23 Pakistani commercial banks to find out the factors that had an impact on the profitability of the banks. His results concluded that cost efficiency, liquidity and capital adequacy had a significant impact on the selected commercial banks in Pakistan. Samad (2015) tried to find out the significant determinants of profitability of the banks. He analyzed the financial data of 42 commercial banks in Bangladesh to reach to a conclusion. He found that loan-deposit ratio, loan-loss provision to total asset ratio, equity capital to total asset ratio and operating expenses to total asset ratio were the significant determinants of profitability of the banks. Ahsan (2016) measured the performance of Islamic banks in Bangladesh regarding capital adequacy, asset quality, management quality, earnings quality and liquidity performance. He used the loan to asset ratio as the indicator of liquidity of the banks.

\section{Research Methodology and Design}

This study was executed using the financial statements of the banks. The sample of the study was seven conventional banks in Bangladesh. The selected banks are:

- AB Bank Limited

- Bank Asia Limited

- Dhaka Bank Limited

- Eastern Bank Limited

- Mercantile Bank Limited

- Premier Bank Limited

- Prime Bank Limited

The equations used in this study are as follows:

$$
\begin{aligned}
& \text { i. Net Interest Margin (NIM) }=\frac{\text { Net Interest Income }}{\text { Total Asset }} \\
& \text { ii. Loan to Deposit Ratio (LD) }=\frac{\text { Total Loans and Advances }}{\text { Total Deposit }} \\
& \text { iii. Cash to Asset Ratio (CA) }=\frac{\text { Total Cash }}{\text { Total Asset }} \\
& \text { iv. Loan to Asset Ratio (LA) }=\frac{\text { Total Loans and Advances }}{\text { Total Asset }}
\end{aligned}
$$

The period of the study covered five years from 2011 to 2015 using the statistical tools (mean value, standard deviation (SD) or variation, maximum (max), minimum (min), correlations and regression analysis). SPSS 16 software was employed to analyze the data of the study.
Where,

$Y_{\text {it: }}$ Represents NIM for Bank $\mathrm{i}$ at time $\mathrm{t}$

$\beta_{0}$ : Represents the intercept

$\beta_{1}, \beta_{2}, \beta_{3}$ : Represents the coefficients of regression relations Eit: Represents the error term

The hypothesis of the study:

Null Hypothesis, $\mathrm{H}_{0}$ : There was no relationship among NIM, LD, CA and LA.

Alternative Hypothesis, $\mathrm{H}_{1}$ : There were relationships among NIM, LD, CA, and LA.

\section{RESULTS AND ANALYSIS}

The results of the study were found using descriptive statistics, correlation and regression analysis. The

\begin{tabular}{|c|c|c|c|c|c|}
\hline $\begin{array}{l}\text { Name of } \\
\text { Banks }\end{array}$ & Year & NIM & LD & CA & LA \\
\hline \multirow{5}{*}{$\begin{array}{l}\text { AB Bank } \\
\text { Limited }\end{array}$} & 2011 & 0.0215 & 0.8847 & 0.0606 & 0.6636 \\
\hline & 2012 & 0.0217 & 0.8124 & 0.0548 & 0.6476 \\
\hline & 2013 & 0.0195 & 0.9104 & 0.0542 & 0.7015 \\
\hline & 2014 & 0.0260 & 0.9325 & 0.0562 & 0.7444 \\
\hline & 2015 & 0.0161 & 1.0126 & 0.0594 & 0.7540 \\
\hline \multirow{5}{*}{$\begin{array}{l}\text { Bank Asia } \\
\text { Limited }\end{array}$} & 2011 & 0.0239 & 0.8761 & 0.0595 & 0.7054 \\
\hline & 2012 & 0.0262 & 0.8478 & 0.0467 & 0.6614 \\
\hline & 2013 & 0.0184 & 0.8075 & 0.0588 & 0.6539 \\
\hline & 2014 & 0.0174 & 0.8522 & 0.0595 & 0.6512 \\
\hline & 2015 & 0.0122 & 0.8170 & 0.0553 & 0.6160 \\
\hline \multirow{5}{*}{$\begin{array}{c}\text { Dhaka Bank } \\
\text { Limited }\end{array}$} & 2011 & 0.0229 & 0.8910 & 0.0905 & 0.7234 \\
\hline & 2012 & 0.0207 & 0.8451 & 0.0818 & 0.6794 \\
\hline & 2013 & 0.0231 & 0.8654 & 0.1044 & 0.6903 \\
\hline & 2014 & 0.0179 & 0.8298 & 0.0995 & 0.6484 \\
\hline & 2015 & 0.0114 & 0.8528 & 0.0845 & 0.6669 \\
\hline \multirow{5}{*}{$\begin{array}{c}\text { Eastern } \\
\text { Bank } \\
\text { Limited }\end{array}$} & 2011 & 0.0287 & 1.0778 & 0.0512 & 0.6895 \\
\hline & 2012 & 0.0332 & 1.0597 & 0.0734 & 0.6589 \\
\hline & 2013 & 0.0313 & 0.8829 & 0.0517 & 0.6533 \\
\hline & 2014 & 0.0236 & 1.0282 & 0.0594 & 0.6920 \\
\hline & 2015 & 0.0193 & 1.0512 & 0.0573 & 0.7036 \\
\hline \multirow{5}{*}{$\begin{array}{c}\text { Mercantile } \\
\text { Bank } \\
\text { Limited }\end{array}$} & 2011 & 0.0149 & 0.8479 & 0.0596 & 0.6834 \\
\hline & 2012 & 0.0129 & 0.7912 & 0.0787 & 0.6113 \\
\hline & 2013 & 0.0112 & 0.8070 & 0.0717 & 0.6725 \\
\hline & 2014 & 0.0152 & 0.8684 & 0.0763 & 0.6933 \\
\hline & 2015 & 0.0137 & 0.8573 & 0.0720 & 0.6890 \\
\hline \multirow{5}{*}{$\begin{array}{l}\text { Premier } \\
\text { Bank } \\
\text { Limited }\end{array}$} & 2011 & 0.0232 & 0.8201 & 0.0686 & 0.6641 \\
\hline & 2012 & 0.0213 & 0.7786 & 0.0639 & 0.6388 \\
\hline & 2013 & 0.0176 & 0.7076 & 0.0602 & 0.5861 \\
\hline & 2014 & 0.0173 & 0.7557 & 0.0652 & 0.6279 \\
\hline & 2015 & 0.0179 & 0.8387 & 0.0649 & 0.6948 \\
\hline \multirow{5}{*}{$\begin{array}{l}\text { Prime Bank } \\
\text { Limited }\end{array}$} & 2011 & 0.0225 & 0.8873 & 0.0671 & 0.7055 \\
\hline & 2012 & 0.0244 & 0.9070 & 0.0680 & 0.6930 \\
\hline & 2013 & 0.0177 & 0.7879 & 0.0719 & 0.6476 \\
\hline & 2014 & 0.0111 & 0.7457 & 0.0685 & 0.5957 \\
\hline & 2015 & 0.0050 & 0.7950 & 0.0691 & 0.6110 \\
\hline
\end{tabular}
corresponding tables and discussion of the results are as follows.

Table 1: Ratio analysis of the banks

The regression equation is,

$Y_{i t}=\beta_{0}+\beta_{1}(L D)+\beta_{2}(C A)+\beta_{3}(L A)+\varepsilon_{i t}$ 
Table 2: Descriptive Statistics of the ratios for each bank

\begin{tabular}{|c|c|c|c|c|c|c|c|c|}
\hline & & $\begin{array}{c}\text { AB } \\
\text { Bank }\end{array}$ & $\begin{array}{c}\text { Bank } \\
\text { Asia }\end{array}$ & $\begin{array}{c}\text { Dhaka } \\
\text { Bank }\end{array}$ & $\begin{array}{c}\text { Eastern } \\
\text { Bank }\end{array}$ & $\begin{array}{c}\text { Mercantile } \\
\text { Bank }\end{array}$ & $\begin{array}{c}\text { Premier } \\
\text { Bank }\end{array}$ & $\begin{array}{c}\text { Prime } \\
\text { Bank }\end{array}$ \\
\hline \multirow{4}{*}{ NIM } & Mean & .021 & .020 & .019 & .027 & .014 & .020 & .016 \\
\cline { 2 - 9 } & SD & .004 & .006 & .005 & .006 & .002 & .003 & .008 \\
\cline { 2 - 9 } & Min. & .016 & .012 & .011 & .019 & .011 & .017 & .005 \\
\cline { 2 - 9 } & Max. & .026 & .026 & .023 & .033 & .015 & .023 & .024 \\
\hline \multirow{4}{*}{ LD } & Mean & .912 & .840 & .857 & 1.020 & .834 & .780 & .825 \\
\cline { 2 - 9 } & SD & .073 & .028 & .023 & .079 & .034 & .052 & .069 \\
\cline { 2 - 9 } & Min. & .812 & .808 & .830 & .883 & .791 & .708 & .746 \\
\cline { 2 - 9 } & Max. & 1.013 & .876 & .891 & 1.078 & .869 & .839 & .907 \\
\hline \multirow{5}{*}{ CA } & Mean & .057 & .056 & .092 & .059 & .072 & .065 & .069 \\
\cline { 2 - 9 } & SD & .003 & .006 & .010 & .009 & .007 & .003 & .002 \\
\cline { 2 - 8 } & Min. & .054 & .047 & .082 & .051 & .060 & .060 & .067 \\
\cline { 2 - 8 } & Max. & .061 & .060 & .104 & .073 & .079 & .069 & .072 \\
\hline \multirow{4}{*}{ LA } & Mean & .702 & .658 & .682 & .680 & .670 & .642 & .651 \\
\cline { 2 - 8 } & SD & .047 & .032 & .028 & .022 & .034 & .041 & .049 \\
\cline { 2 - 8 } & Min. & .648 & .705 & .648 & .653 & .611 & .586 & .596 \\
\cline { 2 - 8 } & Max. & .754 & .616 & .723 & .704 & .693 & .695 & .706 \\
\hline
\end{tabular}

Table 1 presents the ratio analysis of seven selected banks during 2011-2015 and Table 2 presents the descriptive statistics of the ratios for each bank. From the tables, it is observed that AB Bank Limited and Mercantile Bank Limited had Highest NIM in 2014 whereas Bank Asia Limited, Eastern Bank Limited, and Prime Bank Limited had highest NIM in 2012. The NIM of Dhaka Bank Limited Was the maximum in 2013 and of Premier Bank Limited was the maximum in 2011. The loan to deposit ratio (LD) was maximum in 2011 of Bank Asia Limited, Dhaka Bank Limited, and Eastern Bank Limited. Prime Bank Limited and Mercantile Bank Limited had maximum LD in 2012 and 2014 whereas AB Bank Limited and Premier Bank Limited experienced Maximum LD and Ca in 2015. The highest value of CA of Eastern Bank Limited and Mercantile Bank Limited came in 2012 whereas Dhaka Bank Limited and Prime Bank Limited had the highest CA in 2013. Bank Asia Limited had maximum CA in 2014. The loan to asset ratio of Bank Asia Limited, Dhaka Bank Limited, and Prime Bank Limited was the maximum in 2011while AB Bank Limited, Eastern Bank Limited and Premier Bank Limited experienced maximum LA in 2015. And the maximum LA of Mercantile Bank Limited came in 2014. The maximum variation, SD of NIM and LA were of Prime Bank Limited, and highest SD of LD and CA were of Eastern Bank Limited and Dhaka Bank Limited.

Table 3: Descriptive statistics of all the banks

\begin{tabular}{|c|c|c|c|c|}
\hline & Minimum & Maximum & Mean & Std. Deviation \\
\hline NIM & .0136 & .0272 & .019457 & .004245 \\
\hline LD & .7802 & 1.0200 & .866629 & .078026 \\
\hline CA & .0560 & .0921 & .066983 & .012617 \\
\hline LA & .6423 & .7022 & .669112 & .020640 \\
\hline
\end{tabular}

The descriptive statistics of all the banks together is summarized in Table 3. From the Table it is seen that the mean value of NIM, LD, CA and LA of all the banks were $1.95 \%, 86.66 \%, 6.70 \%$ and $66.91 \%$ respectively. The variation of the loan to deposit ratio was the most of all the banks as the standard deviation of LD was $7.80 \%$ whereas the lowest standard deviation came in NIM which was $0.42 \%$.
Table 4: Correlation analysis

\begin{tabular}{|c|c|c|c|c|c|}
\hline & & NIM & LD & CA & LA \\
\hline \multirow{3}{*}{ NIM } & Pearson Correlation & 1 & $.797^{*}$ & -.380 & .346 \\
\hline & \begin{tabular}{|l|} 
Sig. (2-tailed) \\
\end{tabular} & & .032 & .401 & .447 \\
\hline & $\mathrm{N}$ & 7 & 7 & 7 & 7 \\
\hline \multirow{3}{*}{ LD } & Pearson Correlation & $.797^{*}$ & 1 & -.288 & .651 \\
\hline & Sig. (2-tailed) & .032 & & .532 & .113 \\
\hline & $\mathrm{N}$ & 7 & 7 & 7 & 7 \\
\hline \multirow{3}{*}{ CA } & Pearson Correlation & -.380 & -.288 & 1 & .038 \\
\hline & Sig. (2-tailed) & .401 & .532 & & .935 \\
\hline & $\mathrm{N}$ & 7 & 7 & 7 & 7 \\
\hline \multirow{3}{*}{ LA } & Pearson Correlation & .346 & .651 & .038 & 1 \\
\hline & \begin{tabular}{|l|} 
Sig. (2-tailed) \\
\end{tabular} & .447 & .113 & .935 & \\
\hline & $\mathrm{N}$ & 7 & 7 & 7 & 7 \\
\hline
\end{tabular}

Table 4 is the summary of correlation analysis of the net interest margin and liquidity risk ratios. The table showed that NIM had a significant positive relationship $(r=0.797)$ with LD. NIM was also positively related to LA but negatively related to CA. $\mathrm{LD}$ and CA were also negatively related $(\mathrm{r}=-0.380)$ whereas LA had a positive relationship with LD and CA.

Table 5: Regression analysis

\begin{tabular}{|c|c|c|c|c|c|c|c|}
\hline \multicolumn{8}{|c|}{ Coefficients $^{a}$} \\
\hline \multirow[t]{2}{*}{ Model } & \multicolumn{2}{|c|}{$\begin{array}{c}\text { Unstandardized } \\
\text { Coefficients }\end{array}$} & \multirow{2}{*}{\begin{tabular}{|c|}
$\begin{array}{c}\text { Standardized } \\
\text { Coefficients }\end{array}$ \\
Beta
\end{tabular}} & \multirow[t]{2}{*}{$\mathrm{t}$} & \multirow[t]{2}{*}{ Sig. } & \multicolumn{2}{|c|}{$\begin{array}{c}\text { Collinearity } \\
\text { Statistics }\end{array}$} \\
\hline & $\mathrm{B}$ & Std. Error & & & & Tolerance & VIF \\
\hline (Constant) & .013 & .047 & & .283 & .796 & & \\
\hline LD & .051 & .025 & .938 & 2.034 & .135 & .478 & 2.090 \\
\hline $\mathrm{CA}$ & -.034 & .118 & -.100 & -.286 & .793 & .829 & 1.206 \\
\hline LA & -.054 & .091 & -.261 & -.590 & .596 & .521 & 1.920 \\
\hline \multicolumn{4}{|l|}{$\mathrm{R}$} & \multicolumn{4}{|l|}{0.834} \\
\hline \multicolumn{4}{|c|}{ R Square } & \multicolumn{4}{|l|}{0.695} \\
\hline \multicolumn{4}{|c|}{ Adjusted R Square } & \multicolumn{4}{|l|}{0.390} \\
\hline
\end{tabular}

The regression result from Table 5 indicated that the independent variables of the study (LD, CA and LA) could explain the changes in the pair variable NIM by $70 \%$. So, the null hypothesis, $\mathrm{H} 0$ was rejected.

\section{Conclusion}

Conventional banks earned interest from the borrowers and provide interest to the lenders. The difference between the interest income and interest expenses constitutes net interest income and the net interest income is divided by total asset to calculate net interest margin (NIM). This study was an effort to determine the effect of liquidity risk ratios to NIM of the conventional banks in Bangladesh over the period of 20112015. By analyzing the financial data of the banks, researchers found that there was a significant influence of liquidity risk on the NIM of the selected banks. NIM had a positive relationship with LD, CA, and LA where the most significant relationship existed between LD and NIM. It indicated that the more loan and advances provided compared to collect the deposit from customers the higher the NIM of the banks.

\section{ACKNOWLEDGEMENT}

The authors wish to thank Md. Jahangir Alam Siddikee, Assistant Professor, Department of Finance and Banking, Hajee Mohammad Danesh Science and Technology University, Bangladesh for his support and guidance to accomplish the research work. 


\section{REFERENCES}

Ahsan M. K. (2016). "Measuring financial performance based on CAMEL: A study on selected Islamic banks in Bangladesh," Asian Business Review, vol. 6, no: 13, pp. 47-56.

Béjaoui R. \& Bouzgarron H. (2014). "Determinants of Tunisian Bank Profitability," The International Journal of Business and Financial Research, vol. 8 no. 4, pp. 121-131.

Dawood U. (2014). "Factors Impacting Profitability of Commercial Banks in Pakistan for the Period of (20092012)," International Journal of Scientific Research Publications, vol. 4, no. 3, pp. 1-7.

Hamadi H. \& Awdeh A. (2012). "The determinants of bank net interest margin: Evidence from the Lebanese banking sector," Journal of Money, Investment and Banking, vol. 3, pp. $85-98$.

Lartey V. C., Antwi S. \& Boadi E. K. (2013), “The Relationship between Liquidity and Profitability of the Listed Banks in Ghana," International Journal of Business and Social Science, vol. 4, no 3, pp. 48-56.
Raharjo P. G., Hakim D. B., Manurang A. H. \& Maulana T. N. A. (2014). "The Determinant of Commercial Bank's Interest Margin in Indonesia: An Analysis of Fixed Effect Panel Regression," International Journal of Economics and Financial Issues, vol. 4, no. 2, pp. 295-308.

Rahman M. M., Hamid M. K. \& Khan M. A. M. (2015). "Determinants of bank profitability: Empirical evidence from Bangladesh," International Journal of Business and Management, vol. 10, no. 8, pp. 135-150.

Saksonova S. (2014). “The Role of Net Interest Margin in Improving Bank's Asset Structure and Assessing the Stability and Efficiency of Their Operations," Procedia-Social and Behavioral Sciences, vol. 150, pp.132-141.

Samad A. (2015). "Determinants bank profitability: Empirical evidence from Bangladesh," International Journal of Financial Research, vol. 6, no. 3, pp. 173-179.

Youssef A. \& Samir O. (2015). “A comparative study on the financial performance of Islamic and Conventional Banks: Egypt Case," The Business and Management Review, vol. 6, no. 4, pp. 161-175. 